\title{
Introduction: the promise of ageing labour forces
}

\section{Philip Taylor}

\section{INTRODUCTION}

From debates about the restructuring of economies, to the adjustment of social welfare systems, to redefining the concept of old age, older workers have been at the vanguard of developed economies' efforts to respond first, to industrial decline and reorganization in the last three decades, and latterly, the so-called looming crisis facing social welfare systems, associated with population ageing. This volume examines the notion of retiring later, considering the evolution of national policymaking and the behaviour of employers, addressing the question of whether older workers can look forward to the prospect of longer working lives with choice and security and make successful transitions to non-work.

Listening to policy makers and some commentators might make one optimistic that older workers are on the threshold of a new era of opportunity, a 'golden age' of job openings and flexible retirement. This volume tests the validity of this claim, focusing on developments in a small number of industrialized nations: Australia, Canada, France, Germany, Japan, the Netherlands, the United Kingdom and the USA. Nowadays, the necessity for economies, and the value for both industry and older people of extending working lives seems to be taken for granted and dissenting voices are seldom heard. Quickly it seems that a remarkable consensus among policy makers, employers, trade unions and social commentators has emerged. This volume takes a close look at the relatively recent shift away from rhetoric and action of early retirement towards that of 'active ageing', seeking to understand the motives and behaviour of key actors, examining recent trends in older workers' labour force participation and offering an assessment of their likely position into the future.

This chapter begins with a brief overview of the recent history of older workers before moving on to discuss the changing policy landscape. 


\section{DECADES OF EARLY EXIT}

The final quarter of the twentieth century saw the growth of early retirement as a phenomenon. Most industrialized nations, and some European ones in particular, have seen a decline, sometimes marked, in labour force participation rates (defined as the proportion in employment and those seeking work) among older workers. Table I.1 shows the scale of the decline, substantial in much of Europe, rather less in Japan and the USA. The range within Europe is also striking. This downward trend continued until recently, but noticeable is a recent slowing and in some countries, a modest reversal. Perhaps older workers are on the verge of a new era of employment opportunity, the subject of this volume.

As a backdrop to current debates, it is important to consider their changing status in some detail. Their declining participation is explained, to a large extent, by massive restructuring of industry, which has been a feature of most major economies, and has frequently involved the removal of those considered no longer able to do the job or unwilling to change, as industries such as manufacturing and finance sought to reorganize. For others, their jobs disappeared along with whole parts of the industries in which they worked. Relatively generous pension or redundancy settlements have sometimes been used to lever such workers out of jobs. In some countries, early retirement pathways emerged with generous state support. 'Redundant' older workers often made the transition to retirement while aged in their 50s, sometimes without the need to look for alternative employment, with state support that frequently undermined normal ages at which pensions could be claimed.

The result has been the breakdown of the three phase model of the life course: education, work and rest. 'Socially assigned' economic inactivity has, for some, made the last stage 'unforeseeable and uncertain' (Guillemard and Argoud, 2004: 168). Guillemard argues that the passage from work to retirement has undergone a profound shift, with 'an increasing number of in-between, usually unstable, statuses between work and retirement' (1997: 451). While early retirement has often been portrayed as an opportunity to enter a life of leisure, free from the stresses of working life and while in good health, in fact, the reality, as some older people have found out too late, is often very different. Research studies have shown that while, for some, it is welcomed and can come as a relief, many others would have preferred to stay on or at least have chosen their time of retirement. Most thought they might easily move into new, often part-time, jobs but the reality is that a lifetime's experience has often counted for little. What should be a period of winding down and relaxation can turn into an anxious wait and an inevitable scaling back of ambitions. 
Table I.1 Trends in labour force participation rates among people aged 55-64 among the OECD countries (\%)

\begin{tabular}{|c|c|c|c|c|c|c|c|c|c|c|}
\hline & \multicolumn{5}{|c|}{ Men } & \multicolumn{5}{|c|}{ Women } \\
\hline & 1983 & 1990 & 1995 & 2000 & 2004 & 1983 & 1990 & 1995 & 2000 & 2004 \\
\hline Australia & 62.0 & 63.2 & 60.8 & 61.2 & 64.4 & 20.5 & 24.9 & 28.6 & 36.1 & 43.1 \\
\hline Austria & - & - & 42.6 & 44.5 & 38.6 & - & - & 18.8 & 18.9 & 19.3 \\
\hline Belgium & 50.6 & 35.4 & 35.9 & 36.3 & 41.0 & 12.3 & 9.9 & 13.3 & 15.8 & 21.8 \\
\hline Canada & 72.4 & 64.0 & 58.9 & 61.0 & 66.0 & 33.5 & 34.8 & 36.3 & 41.6 & 49.0 \\
\hline $\begin{array}{l}\text { Czech } \\
\text { Republic }\end{array}$ & - & - & 52.0 & 54.5 & 60.1 & - & - & 21.3 & 23.7 & 31.3 \\
\hline Denmark & 67.2 & 69.1 & 67.9 & 64.5 & 73.3 & 41.7 & 45.9 & 40.1 & 48.2 & 57.6 \\
\hline Finland & 54.1 & 47.1 & 44.6 & 48.1 & 55.7 & 47.4 & 40.8 & 41.9 & 45.2 & 54.3 \\
\hline France & 53.6 & 39.3 & 41.5 & 41.7 & 44.3 & 32.7 & 26.9 & 30.9 & 33.0 & 35.0 \\
\hline Germany & 63.1 & 55.9 & 54.5 & 52.4 & 54.8 & 26.3 & 24.7 & 31.3 & 33.5 & 33.8 \\
\hline Greece & 70.8 & 59.5 & 61.1 & 57.3 & 58.7 & 25.7 & 24.3 & 24.5 & 25.5 & 25.3 \\
\hline Hungary & - & 35.3 & 28.6 & 34.1 & 39.7 & - & 15.1 & 9.7 & 13.3 & 25.8 \\
\hline Iceland & - & 93.5 & 92.7 & 94.7 & 89.7 & - & 81.1 & 84.8 & 76.8 & 78.8 \\
\hline Ireland & 78.0 & 65.0 & 63.9 & 64.7 & 66.6 & 20.2 & 19.9 & 21.2 & 27.8 & 34.5 \\
\hline Italy & 56.2 & 53.0 & 44.1 & 42.7 & 44.0 & 15.0 & 15.5 & 13.8 & 16.1 & 20.4 \\
\hline Japan & 97.1 & 83.3 & 84.8 & 84.1 & 82.5 & 46.1 & 47.2 & 48.5 & 49.7 & 50.1 \\
\hline Korea & - & 77.2 & 79.7 & 71.0 & 73.5 & - & 49.6 & 50.4 & 48.6 & 46.5 \\
\hline Luxembourg & 37.8 & 43.2 & 35.1 & 38.6 & 39.1 & 14.7 & 13.8 & 13.3 & 16.8 & 23.3 \\
\hline Mexico & - & 85.9 & 80.7 & 80.8 & 81.5 & - & 24.4 & 26.9 & 28.6 & 32.0 \\
\hline Netherlands & 54.1 & 45.8 & 42.3 & 50.8 & 58.7 & 13.4 & 16.8 & 18.6 & 26.4 & 33.6 \\
\hline New Zealand & - & 56.8 & 65.3 & 72.2 & 78.2 & - & 30.7 & 39.0 & 48.0 & 59.6 \\
\hline Norway & 80.3 & 72.8 & 72.3 & 74.4 & 74.3 & 53.1 & 53.9 & 57.4 & 61.6 & 63.1 \\
\hline Poland & - & 48.1 & 45.5 & 40.4 & 41.3 & - & 29.6 & 27.6 & 23.7 & 23.3 \\
\hline Portugal & 70.7 & 66.5 & 61.9 & 64.5 & 62.8 & 32.6 & 32.3 & 34.5 & 41.9 & 44.8 \\
\hline $\begin{array}{l}\text { Slovak } \\
\text { Republic }\end{array}$ & - & - & - & 41.0 & 51.9 & - & - & - & 10.7 & 14.8 \\
\hline Spain & 71.5 & 62.5 & 54.9 & 60.5 & 62.7 & 20.3 & 19.4 & 19.9 & 22.6 & 27.2 \\
\hline Sweden & 77.0 & 75.5 & 70.7 & 72.8 & 76.0 & 59.7 & 65.8 & 63.7 & 65.9 & 70.2 \\
\hline Switzerland & - & 86.4 & 82.3 & 79.3 & 79.1 & - & 43.8 & 58.7 & 51.3 & 55.7 \\
\hline Turkey & - & 61.3 & 60.9 & 53.4 & 49.0 & - & 26.6 & 26.1 & 21.6 & 19.8 \\
\hline UK & 70.0 & 68.1 & 62.4 & 63.3 & 68.0 & 36.1 & 38.7 & 40.8 & 42.6 & 48.3 \\
\hline EU-15 & 62.8 & 55.4 & 51.9 & 52.3 & 55.2 & 26.6 & 25.7 & 28.0 & 30.9 & 34.5 \\
\hline EU-19 & - & 54.3 & - & 51.1 & 54.0 & - & 25.8 & - & 29.5 & 33.1 \\
\hline $\begin{array}{c}\text { EU (OECD } \\
\text { Europe) }\end{array}$ & 62.9 & 55.5 & 52.4 & 51.9 & 54.2 & 27.6 & 26.4 & 27.8 & 29.5 & 32.7 \\
\hline USA & 69.4 & 67.8 & 66.0 & 67.3 & 68.7 & 41.5 & 45.2 & 49.2 & 51.9 & 56.3 \\
\hline All OECD & 80.6 & 65.0 & 62.7 & 62.8 & 64.7 & 34.5 & 34.7 & 36.4 & 38.8 & 42.2 \\
\hline
\end{tabular}

Source: OECD Employment Outlook (various). 
However some older workers are denied even this minimal level of security. These workers have been caught on the tide of massive shifts in industry which have taken place over the last 25 years. Gone are many of the industries in which they predominated. When they disappeared, some older workers were left high and dry without even a modest financial settlement. Once out in the job market many found their skills ill-suited to the demands of the new economy or that their age counted against them. Many never worked again. This has often meant years of unemployment, or something akin to this, before reaching the relative safety of retirement. Of course, any savings are usually long since exhausted, eliminating any prospect of a relatively comfortable old age.

What accounts for the problems faced by many older workers? First is society's preference for youth. The young are seen by many as our future while older people are seen as having nothing new to offer. A large body of evidence demonstrates that older workers face considerable discrimination in the labour market. Not only are they overrepresented among those targeted first for redundancy; once in the labour market they find themselves facing considerable age barriers. An OECD study found that, among nine European Union countries, the share of older workers among recent job hires was almost 13 percentage points lower than so called 'prime-age' workers (OECD, 1998a). For example, managers sometimes express concerns about the pay-back period on investments in training, that older workers are marking time until retirement, and that their work performance in key regards is lower than younger workers (for instance, see AARP, 2000; Taylor and Walker, 1994). As a result, non-working older workers may find it difficult to find re-employment, except on the lowpay/low security periphery of the labour market. Older workers in employment sometimes find themselves denied access to training opportunities or are passed over for promotion, simply because they have crossed a particular age threshold. This makes them vulnerable if a reduction in the workforce headcount is required.

Second, and importantly, until recently, many European governments gave tacit, and some overt support to employers wishing to dispense with older labour. For some individuals, the ability to make use of early retirement pathways alleviated much of the distress of unrealistic job-search. This particular part of the recent history of older workers has been considered thoroughly by others, particularly Kohli et al. in the seminal Time for Retirement (1991) and more recently by Casey (1998) and there is no need to cover old ground, but it should be noted that this backdrop to present-day policy efforts explains their origins, scope and some of the challenges they are facing. This particularly applies to countries with welldeveloped early exit pathways such as France and Germany. As Guillemard 
and Argoud (2004) note, while popular, early retirement in France has created other problems, contributing to a general devaluation of older labour at earlier and earlier ages. Companies, trade unions and employees have colluded in the perpetuation of a system where 55 has become 'the normal age for definitively leaving the labour market' (p. 177). Such a situation has not only had a profoundly negative effect on how such workers are viewed by managers and supervisors, but moreover, workers aged in their 40s are now viewed as 'nearly old' and find their career prospects severely curtailed (p. 178).

Third, evidence shows that older workers sometimes help perpetuate ageist myths. Some wrongly believe that retraining is unnecessary or that they are too old to retrain. Others believe that, at their age, no employer would take them on anyway. On the other hand, some believe that the barrier is their age when it is not. Thus, 'ageism' is often internalized by older people and making way for younger workers has even been presented as a reason for taking early retirement (Taylor and Walker, 1996a, b).

Of course, and this often appears to have been overlooked recently by public policymakers keen to emphasize a clear shift in favour of older workers' employment as, they argue, industry increasingly recognizes the business case for employing older workers, early retirement and what appear to be overtly ageist employment practices continue into the twentyfirst century. A couple of examples will serve to illustrate this point. One is the German firm KSB (Taylor, 2006), a world-leading manufacturer of pumps and valves for private and industrial applications. This company implemented a 'programme for older employees' in 2003, which included a range of measures aimed at the integration and retention of its older workers. However any positive vision of workforce ageing this attempted to engender was subsequently threatened as management responded to changing business conditions. One year after launching this measure, a rationalization and reorganization programme was implemented by the company, which led to a wave of compulsory early retirements. This approach was regarded by management as the most socially acceptable solution to the company's problems.

Another recent example again demonstrates that competitive pressures can lead companies into actions that could be viewed as being overtly ageist. The company is Ericsson, which announced in the spring of 2006 that it was offering voluntary severance to up to 1000 employees aged 35 to 50 in order to make way for younger workers. The telecommunications equipment maker stated that its workforce had become unbalanced after major job losses at the beginning of the decade and it needed to recruit younger staff in order to ensure competitiveness. It was stated 
that the measure would include a generous financial package and retraining (Financial Times, 2006).

These are not unusual occurrences as corporations seek to maintain competitive advantage. It is possible to counter that the literature is littered with examples of good employment practice and guidance aimed at supporting the integration of older workers (for instance, Buck and Dworschak, 2003; Buck et al., 2002; Dennis, 1988; Health Education Authority, 1994; Ilmarinen, 1999; Kuhn, 1997; McNair and Flynn, 2005; Naegele and Walker, 2006; Pack et al., 1999; Taylor, 2006; The Commonwealth Fund, 1991; Walker and Taylor, 1998; Worsley, 1996). In the drive for competitiveness and greater efficiency businesses have often being unwittingly drained of vast reservoirs of skills and experience which are then lost forever, but recently, a few employers have begun to recognize that older workers have things to offer and that a blend of youth and experience has business benefits. Some have recognized that the tacit knowledge amassed by older workers can be an important source of competitive advantage and have thus abandoned early retirement schemes in favour of compulsory, performance-based, schemes, thus retaining the best team on the pitch, not necessarily the youngest. Organizations that have not, have often subsequently regretted the loss of corporate memory caused by the removal of older workers. Additionally, some employers are beginning to look at other ways in which they can remove age barriers. For example, some have included statements such as 'older people welcome to apply' in recruitment advertisements, some provide age awareness training for staff while others provide career planning workshops for workers aged in their 50s. Others offer special leave for those caring for elderly relatives and a few encourage older people to come back in a consultancy capacity after they have officially retired or run mentoring schemes whereby older workers can pass on the benefits of their experience to younger workers. Some leading companies and government departments are implementing policies aimed at making retirement more flexible. Employers have reported business benefits in terms of employee job satisfaction, increased sales and better customer relations.

Yet against the background of a scarcity of labour and relatively buoyant economies, it is hardly a surprise that some organizations have demonstrated an interest in older workers. What is not generally acknowledged is the continuing pressure that older workers are under as they confront what Sennett (2006) describes as the 'spectre of uselessness' as the forces of globalization undermine their position in labour markets, with jobs they could do moving elsewhere and employers being unwilling to invest in the level of skills training that might give them a solid foothold in the labour market. Sennett's is a rare cautionary voice nowadays. 


\section{MEETING THE CHALLENGES OF AN AGEING SOCIETY. TOWARDS ACTIVE AGEING}

Paradoxically, as the age at which we have retired has been lowered, our societies have been ageing. Global ageing is a fact and the populations of the developed economies are the oldest. It is projected that Europe will be most affected by population ageing, with the proportion of people aged 60 or over increasing from 20 per cent to 35 per cent by 2050. Southern Europe is the world's region with the oldest population - 22 per cent in 1998 - and predicted to increase to 39 per cent by 2050 . In 1998, Italy had the world's oldest population, followed by Greece, Japan, Spain and Germany. By 2050 Spain will have the world's oldest population, followed by Italy. After Europe and Japan, the other areas particularly affected by ageing are, in decreasing order, North America, Oceania, Asia and Latin America and the Caribbean (Auer and Fortuny, 2000).

Europe and Japan, in particular, with the most rapidly ageing societies, are increasingly viewing this as a strategic issue, though it is also on the agenda elsewhere. Our economic futures, it is argued, depend on meeting the challenges of an ageing society. The OECD summed up much of the tone of the current debate in its publication: Maintaining Prosperity in an Ageing Society (OECD, 1998b). Shrinking populations and labour shortfalls, which most observers think will only be partially offset by immigration, are predicted. In a relatively short space of time, discussion of the attainment of a leisure society has been replaced by a work-centred perspective.

Consideration of the needs of older workers is far from new. For instance, in 1980 the General Conference of the International Labour Organization made a number of recommendations which stand scrutiny today. But in recent times, a huge number of official reports, conferences and programmes of research in the industrialized nations have considered issues of workforce ageing. An exhaustive review would be virtually impossible and anyway, almost immediately out of date, but the theme is always a similar one: working lives need to be extended if social welfare systems are to be sustainable and there is to be an adequate supply of labour going forward. Many observers have pointed to the failure of early retirement to create jobs for younger people, a key objective (for instance, World Bank, 1994), and there is a burgeoning literature concerning economic and social aspects of population ageing which serves to provide an evidence base for the argument that working later is a necessity (for instance, Access Economics Pty Limited, 2001; Bertelsmann Foundation, 2006; Bundesministerium fur Bildung und Forschung, 1999; Committee for Economic Development, 1999; Confederation of German Employers' Associations, 2003; Employment 
Observatory, 1999; Eurolinkage, 1997; European Foundation for the Improvement of Living and Working Conditions, 1992; Johnson and Zimmerman, 1993; Pearson, 1996; Performance And Innovation Unit, 2000; Productivity Commission and Melbourne Institute of Applied Economic and Social Research, 1999; The Geneva Association and GINA, 2002; The Victorian, South Australian and Western Australian Equal Opportunity Commissions and the Australian Employers' Convention, 2001).

Principal among recent reviews is a major thematic study undertaken by the OECD of older workers and employment policy among member states (OECD, 2005) which shows that, at national level a range of reforms are now stepping up efforts aimed at stopping early exit and extending working lives, while noting barriers to progress (for other recent reviews, see also ETUI, 2002, 2003; Frerichs and Taylor, 2005; Reday-Mulvey, 2003; Taylor, 2002). This builds on earlier national reviews conducted by the International Labour Organization and the European Foundation for the Improvement of Living and Working Conditions into the labour market situation of older workers, age and training and the behaviour of the social actors (for instance, Frerichs, 1996; Guillemard, 1996; Oka, 1992; Sutter, 1989; Taylor and Walker, 1996a, b; Thomas et al., 1992; de Vroom, 1996; Yocum, 1992).

Meanwhile, many media reports of the issue have adopted an almost hysterical tone, characterizing older people as a burden on the young and for the latter's sake, needing to work on, if the 'crisis' that is global population ageing is to be averted. To be fair, much of both the policy and academic literatures on the ageing of populations has been similarly strident, using the language of crisis and threat rather than challenge and opportunity. Again, there have been a modest number of attempts to provide qualifications and critical commentary (for an example, see Working Group on the Implications of Demographic Change, 2002). It should also be noted, because it helps put present discussions in context, that only recently older workers were being pressured to make way for the young. Either way, it seems, they are quite often viewed as a 'problem'.

According to Burniaux et al., (2004), in many OECD countries demographic changes will result in significant declines in the growth (and sometimes the levels) of the labour force and aggregate participation rates over the coming decades. They calculate that the overall participation rate could fall by $4-5$ percentage points for the OECD on average between 2000 and 2025. At the same time, there will be an increasing share of older workers in the labour force and a significant increase in old-age dependency ratios.

They and many others have argued that by utilizing measures involving additional work incentives for older workers and women and raising the propensity of youth to combine work and education, it will be possible to 
mitigate, offset or, even reverse these adverse demographic effects, at least for the time-being. Reforms with the largest potential effects on participation concern pension systems, particularly those achieving actuarial neutrality of old-age pensions. Additional work incentives for women are also influential and may be politically easier to implement.

Concern about the escalating costs of supporting a growing inactive older population with fewer younger people means that the issues of age discrimination in employment and the extension of working life are now high on the agendas of national governments and increasingly business. It is argued that companies, chasing a shrinking pool of young skilled labour, will face an increasing wage bill if they are to compete in the labour market. They will also risk having a workforce which, in its composition, does not reflect that of the population as a whole, with the possibility that they will lose touch with the needs of their, increasingly older, customer base, who will also be demanding a different type of service and product. For both government and business therefore, population ageing potentially presents serious challenges.

The responses of national governments are addressed in each chapter, but to begin, a brief discussion of European policy will illustrate how far some countries have gone and the distance they will need to travel in order to reach the end of early retirement. The remarkable scale of early exit and the perceived challenges confronting Europe as its population ages explains why European policy makers have devoted so much recent effort to redefining retirement. An 'active' employment policy is central to the vision of Europe set out at the Lisbon Council of the year 2000 where a strategic goal for the decade of becoming 'the most competitive and dynamic knowledgebased economy in the world capable of sustainable economic growth with more and better jobs and greater social cohesion' was established (http://www.europarl.europa.eu/summits/lis 1_en.htm).

Developing this vision, three European level agreements affecting older workers have aimed at influencing public policy at national levels. These are the European Equal Treatment Directive, and the Barcelona and Stockholm targets. In the year 2000 the European Union Council Directive 2000/78/EC established a general framework for equal treatment in employment and occupation. The Directive required all EU countries to introduce legislation proscribing direct and indirect discrimination in terms of labour market activities and vocational training on the grounds of age. The directive allowed Member States until the end of 2006 to implement the provisions on age and allowed considerable latitude as to how the directive was to be implemented. A recent review concluded that transposition of the directive had been uneven, progress being slow in some countries, while others had complied technically, though more could be done. Also, while the Directive 
called for consultation with a range of stakeholders, this had been lacking (Baker, 2004).

Additionally, the EU's taskforce on employment led by Wim Kok (European Union Task force on Employment, 2003), submitted a report to the European Council calling for Member States to take three key measures to meet European targets:

1. Provide incentives for workers to retire later and for employers to hire and keep older workers.

2. Promote access to training for all regardless of age and to develop lifelong learning strategies.

3. To improve the quality of work to provide attractive, safe and adaptable work environments throughout the working life, including the provision of part-time work and career breaks.

Given their status in the European labour market, the European Council of Stockholm in 2001 agreed a remarkably ambitious target for the employment rate of older workers of 50 per cent by the year 2010. This stood at 38.8 per cent in 2001 (European Council, 2001). At the Barcelona European Council it was stated that the burden represented by an ageing population will need to be shared between the generations: 'A progressive increase of about 5 years in the effective average age at which people stop working in the European Union should be sought by 2010' (European Council, 2002). The average exit age from the labour force, regardless of whether they are receiving a pension or not, for the EU was 59.9 years in 2001.

There are a few positive signs, though progress remains modest overall. Only a handful of European Member States have achieved the Stockholm target so far and the European Commission (2003) concludes that the employment of older workers remains a major challenge. In a recent report to the Stockholm European Council it stated that:

For older workers, despite various policy initiatives by the MS [Member States] (as reported in NAPs [National Action Plans]) there is little evidence that these have resulted in significant increases in labour market participation among older workers. To a large extent this reflects a deep-rooted early retirement culture and the persistence of early retirement schemes (often coexisting with schemes aiming at extending older workers' working life) and negative attitudes which remain not only among employers but also trade unions and policy makers. (European Commission, 2001: 23)

In fact, Burniaux et al. (2004) suggest that the kinds of reforms they suggest for the European Union would suffice to meet targets, though they think it unlikely that the effects could materialize by 2010 , as is hoped. 
Table I.2 Changes in employment activity rate for the age group 55-64 years old between 1979 and 2004

\begin{tabular}{lccccccccc}
\hline & \multicolumn{7}{c}{ Men } \\
\cline { 2 - 9 } & 1979 & 1983 & 1990 & 1995 & 2000 & 2001 & 2002 & 2003 & 2004 \\
\hline Australia & 67.4 & 59.6 & 59.2 & 55.3 & 58.5 & 56.6 & 58.1 & 60.7 & 61.7 \\
Canada & 72.9 & 66.4 & 60.0 & 54.0 & 57.7 & 57.3 & 58.9 & 60.8 & 62.0 \\
EU-15 & - & - & 52.3 & 47.2 & 48.5 & 48.6 & 49.8 & 51.3 & 50.4 \\
France & 67.0 & 50.4 & 37.0 & 38.4 & 38.5 & 34.9 & 38.1 & 39.7 & 41.9 \\
Germany* & 63.2 & 57.4 & 52.0 & 48.8 & 46.4 & 46.4 & 47.2 & 47.1 & 48.8 \\
Japan & 81.5 & 80.5 & 80.4 & 80.8 & 78.4 & 77.5 & 76.8 & 77.4 & 78.1 \\
The Netherlands & 63.2 & 44.2 & 44.5 & 31.5 & 50.0 & 50.5 & 54.9 & 57.4 & 56.4 \\
United Kingdom & - & 62.4 & 62.4 & 56.1 & 59.8 & 61.6 & 62.1 & 65.0 & 65.4 \\
United States & 70.8 & 65.2 & 65.2 & 63.6 & 65.7 & 66.0 & 66.3 & 65.6 & 66.0 \\
& & & & & & & & & \\
& & & & & Women & & & & \\
Australia & 19.8 & 19.9 & 24.2 & 27.4 & 35.4 & 35.7 & 38.0 & 39.4 & 41.7 \\
Canada & 32.3 & 30.9 & 32.8 & 33.4 & 39.4 & 39.4 & 41.4 & 45.3 & 46.2 \\
EU & - & - & 24.3 & 25.6 & 28.5 & 29.0 & 30.3 & 32.0 & 30.9 \\
France & 37.0 & 30.4 & 25.0 & 28.9 & 30.3 & 26.7 & 29.6 & 32.7 & 32.5 \\
Germany* & 26.8 & 24.0 & 22.4 & 27.0 & 29.0 & 29.4 & 30.0 & 30.9 & 29.8 \\
Japan & 44.8 & 45.1 & 46.5 & 47.5 & 47.9 & 47.3 & 47.1 & 47.5 & 48.6 \\
The Netherlands & 14.0 & 13.2 & 15.8 & 14.0 & 25.8 & 28.0 & 29.0 & 32.2 & 32.5 \\
United Kingdom & - & - & 36.7 & 39.3 & 41.4 & 43.2 & 44.7 & 46.4 & 47.3 \\
United States & 54.8 & 40.4 & 44.0 & 47.5 & 50.6 & 51.7 & 53.2 & 54.5 & 54.3 \\
\hline
\end{tabular}

Note: * Reunified from 1989.

Source: OECD Employment Outlook (various).

Table I.2 places current the present European debate in sharp relief. This shows employment rates among the 55-64 age group for the countries which formed the case studies for this volume. Europe, overall, clearly lags far behind Japan and the USA, and other industrialized nations such as Australia and Canada. Despite this, as will be demonstrated, reform is also under way in these countries. Japan, like parts of Europe, faces looming problems due to the rapid ageing of its population. Although early exit has never been a major feature of its labour market, immigration, which could offset the effects to some extent, has not found wide acceptance as a policy approach. Pension and labour market reforms are under way in order to maintain the viability of its economy (Kano, 2002). For the USA the problem is somewhat less urgent, due to the relative youthfulness of its 
society, and as with Japan, though to a lesser extent, the participation of older workers in the labour market did not deteriorate as much as it did in Europe. The National Strategy for an Ageing Australia (Department of Health and Ageing, 2002) identified the 'need for and value of better utilising skilled mature age workers [which] will increase as the supply of younger workers declines. Ongoing engagement of mature age workers will be important to achieve sustained economic growth as the population ages' (p. $x$ ).

Added to the obvious benefits for economies of people working later, there is a body of evidence which shows that the option of paid work for an older individual can improve their prospects of experiencing a healthier, a wealthier and a happier old age, offering, according to Robert Butler, continuing social engagement, a sense of purpose and meaning, control over one's life and, on top of this, a wage (www.cenekreport.com/storage/npr $\%$ 20interview_dr $\% 20$ robert $\% 20$ butler_health $\% 20$ benefits $\% 20$ of $\% 20$ workin $\mathrm{g} \%$ 20.pdf).

However the real situation is clearly rather more complex. To return briefly to the discussion of international comparisons of early retirement, Gruber and Wise (1999a) show that social security provisions in many countries have sometimes offered enormous incentives to retire early, which may account for a significant part of the long-term decline in economic activity rates among older males. In continental Europe disability and unemployment programmes have provided generous early retirement benefits well before the official retirement age. Research places the USA alongside Japan in having low levels of non-work among those aged 55-59 and a low implicit tax on work at older ages. This research also places the UK and France together as countries with high levels of non-work among those aged 55-59 and a high implicit tax on work at older ages. Canada and Germany fall between these high and low groups (Gruber and Wise, 1999b). On the other hand, it is also the case that it is Japan and the USA where joblessness among older workers is more likely to be associated with poorer mental health (Taylor, 2003). Moreover, while employment rates among older workers have increased recently, some observers have argued that they have been overrepresented in the expansion of precarious work, and risk ill-health and injury associated with poor work organization, inadequate training and poorer knowledge of hazards and managing them (Quinlan et al., 2001; Quinlan and Bohle, 2003; McGovern et al., 2004). Their job security is also threatened by work intensification and the loss of soft and bridge jobs caused by the introduction of lean production processes (Tros, 2004), while research also points to declining levels of job satisfaction (Green, 2002), associated with the propensity to retire. Importantly, for many of the young and those with high skill levels, temporary jobs provide a stepping stone to jobs of higher quality. Among older and low skilled people, however, less than a third and less than 
40 per cent, respectively, move from a temporary to a permanent job within three years. For these same groups, the risk of becoming unemployed is more than twice as high compared to young people and those with high-level skills (Taylor, 2006).

It seems, therefore, that early retirement's detractors have overlooked some potential benefits, while 'activation' appears to have its problems. While working later may be better, this is probably not all work, and in what sense is unemployment a better scenario than early retirement, other than perhaps in a narrow economic one?

Nevertheless in recent times, the term 'active ageing' has largely replaced 'early retirement' in the policy vernacular (Prager and Schoof, 2006) and bodies such as the World Health Organization (2002) and the European Commission (1999) have been busy promoting the concept. A policy framework for active ageing has been set out by the World Health Organization. Here the concept is defined as: 'the process of optimizing opportunities for health, participation and security in order to enhance quality of life as people age' (WHO, 2002: 12).

Active refers to:

continuing participation in social, economic, cultural, spiritual and civic affairs, not just the ability to be physically active or to participate in the labour force. Active ageing aims to extend healthy life expectancy and quality of life for all people as they age, including those who are frail, disabled and in need of care.

However while a broader term than 'productive ageing', which has been coined to refer to 'any activity by an older individual that produces goods or services, or develops the capacity to produce them, whether they are to be paid or not' (Bass et al., 1993: 6), in reality much of what has emerged from the 'active' ageing recipe book has had a strongly economic flavour. European commentators and policy makers, in particular, have begun to flesh out an active or activating approach to tackling specific issues associated with the extension of working lives. According to Naegele (1999) such an approach concerns both measures aimed at the prevention of unemployment and the reintegration of unemployed workers. It includes tackling age discrimination in the labour market, adapting learning approaches to the circumstances of older people and the adaptation and improvement of working conditions. The primary objective should be to prevent involuntary early retirement.

The European Commission has set out its vision for realizing the greater integration of older workers with the following list of requirements:

- improving their skills, motivation and mobility;

- good practice in lifelong learning is promoted and disseminated; 
- adapting workplaces to workforce ageing to reduce the erosion of work-ability and to extend working lives;

- facilitating access to more suitable and flexible forms of working; and

- removing age-discriminatory attitudes and practices (p. 5).

Elsewhere, it has referred to the need for action in the following domains.

1. A joint government and social partner initiative to extend working lives:

- access to company training;

- improving quality in working conditions and work organization; and

- changing views about the value of early retirement.

2. A targeted review of tax/benefit systems towards enhancing work incentives:

- removing incentives encouraging early retirement both for individuals and for enterprises;

- promoting a partial/gradual transition to retirement;

- reviewing the effects of current policy combinations affecting participation.

3. Reforms aimed at making the care system more responsive to the needs of an ageing population (European Commission, 2002: 12-13).

The European Commission (1999) states that 'Successful active ageing policies involve all generations. All actors (government, firms and workers) need to adopt lifecycle strategies enabling workers of all ages to stay longer in employment' (p. 5). In his keynote introductory report to the European Commission Conference on Active Ageing in 1999, Alan Walker (1999) identified these key themes among others:

- Active ageing has the potential for major social and economic impact via the development of new, more active and employment/activityfriendly approaches with regard to pensions, employment, health and social care and citizenship.

- Bringing together the different elements of policy is essential if active ageing is to become more than a slogan. A multidimensional strategy will integrate individual and collective action and concentrate attention on the whole of the life course, not only older people.

- Achieving active ageing across the life course requires policy makers to adopt holistic and 'joined-up' approaches.

Similarly, the OECD (1998b) has set out the following list of reforms in order for active ageing to be achieved: 
- Greater emphasis on prevention: making inexpensive interventions such as providing public information at an early stage of life and thereby reducing the need for later remedial action.

- Use of remedial interventions that are less fragmented and that are concentrated at critical transition points in life - early identification of problems, use of case management techniques, coordination among various agencies and measurement of outcomes.

- Better balance in the lifetime costs and benefits of programming to provide less constrained choices and greater responsibility at the level of individuals - such as greater linkage of lifetime pension contributions and benefits.

- Without a common strategic framework for reform, changes in one area can offset reforms in another; reforms necessarily cut across traditional programme boundaries.

- A common framework would also improve the quality of ground service delivery by facilitating cooperation among many agencies. There would be opportunity for sharing of lessons learned across disciplines and exchange of data and research results.

The Australian Council on the Ageing (Sheen, 2001; see also Sheen, 2000) goes further, arguing for a five-point strategic plan for older workers which includes issues of labour demand and an adequate social safety net. To summarize:

- maintaining economic growth which will generate sufficient jobs, combined with effective labour force management;

- tackling age discrimination;

- providing adequate opportunities for learning and training;

- flexible jobs and social security provision; and

- an adequate safety net for those unable to work.

The 'active' approach, thus offers a radically different vision of the ageing worker from that of the past. According to Walker (2002: 137) 'it is a strategy that makes sound economic sense, by responding to the economic challenges of ageing and extending employment, and, at the same time, it improves quality of life'. A recent report concluded that 'the most effective and plausible social, and policy, response to an ageing population is to increase the employment rate of the over 50s' (Working Group on the Implications of Demographic Change, 2002). Therefore, in considering such issues, this volume is timely. However although early exit pathways would seem to be anathema to the activating approach, Naegele recommends a cautious examination and weighting of social security features for 
an ageing workforce in order for the activating approach not to be undermined. In his view, an approach which substitutes one kind of exclusion: early retirement, for another: long-term unemployment would be a failure. It is notable that for the WHO also, activation is not just a one way street:

It allows people to realize their potential for physical, social, and mental well being throughout the life course and to participate in society according to their needs, desires and capacities, while providing them with adequate protection, security and care when they require assistance (p. 12).

Although it added that:

The current trend toward early retirement in industrialized countries is largely the result of public policies that have encouraged early withdrawal from the labour force (p. 17).

While in one sense this statement is true, it confuses cause and effect, overlooking a critical factor which lay behind the rise of early retirement, namely declining demand for older workers and the loss of industries in which they predominated. Thus, any consideration of active ageing from a labour market perspective must consider both labour supply and demand. Activating older workers is one thing, but if ageing is to be 'successful' then it would seem that considerations such as opportunity and choice should be applied.

The cautious approach advised by Naegele and others underpinned the construction of this volume. Although proponents of active ageing seem to have a strong case, this needs to be tested. While early retirement now has few defenders, it may still have an important role to play in protecting older workers from the vagaries of labour markets. Chapters are provided by leading experts in the field of age and work in Europe, North America, Japan and Australia. These consist of country reviews where the authors seek to compare the promise of active ageing with the reality of older workers' experiences in the labour market. They examine the ageing of workforces and the changing status of older workers, consider the reform of retirement income systems, the emergence of active labour market policies and the rationale for current actions. They ask whether real progress is being made towards active ageing and set out the critical barriers to extending working lives.

\section{REFERENCES}

AARP (2000), American Business and Older Employees, Washington, DC: AARP. Access Economics Pty Limited (2001), Population and the Economy, Canberra: Commonwealth Department of Health and Aged Care. 
Auer, Peter and Mariangels Fortuny (2000), Ageing of the Labour Force in OECD Countries: Economic and Social Consequences, Geneva: International Labour Organization.

Baker, Richard (2004), 'Age discrimination: implementing the directive in the EU', accessed at http://lawzone.thelawyer.com/cgi-bin/item.cgi?id $=110183 \& \mathrm{~d}=$ pndpr\&h $=$ pnhpr\&f $=$ pn.

Bass, Scott, Frank Caro and Yung-Ping Chen (eds) (1993), Achieving a Productive Ageing Society, London: Auburn House.

Bertelsmann Foundation (2006), Active Aging in Economy and Society, Gütersloh, Germany: Bertelsmann Stiftung.

Bohle, Philip and Michael Quinlan (2000), Managing Occupational Health and Safety, Melbourne: Macmillan.

Buck, Hartmut and Bernd Dworschak (eds) (2003), Ageing and Work in Europe. Strategies at Company Level and Public Policies in Selected European Countries, in the booklet series Demography and Employment, Stuttgart: IRB Verlag.

Buck, Hartmut, Ernst Kistler and Hans G. Mendius (2002), Demographic Change in the World of Work. Opportunities for an Innovative Approach to Work-A German Point of View, Stuttgart: Bundesministerium für Bildung und Forschung.

Bundesministerium für Bildung und Forschung (1999), Congress Ageing and Work, Berlin, November.

Burniaux, Jean-Marc, Romain Duval and Florence Jaumotte (2004), 'Coping with ageing: a dynamic approach to quantify the impact of alternative policy options on future supply in OECD countries', OECD Economics Department working paper 371, OECD, Paris.

Casey, Bernard (1998), 'Incentives and disincentives to early and late retirement', OECD working paper Awp 3.3, Paris.

Committee for Economic Development (CED) (1999), New Opportunities for Older Workers, New York and Washington: CED.

The Commonwealth Fund (1991), New Findings Show Why Employing Workers Over 50 Makes Good Financial Sense for Companies, New York: The Commonwealth Fund.

Confederation of German Employers' Associations (2003), Proage - Facing the Challenge of Demographic Change, Berlin: Confederation of German Employers' Associations.

Dennis, Helen (1988), Fourteen Steps in Managing an Aging Workforce, Lanham, MD: Lexington Books.

Department of Health and Ageing (2002), National Strategy for an Ageing Australia. An Older Australia, Challenges and Opportunities for All, Canberra, accessed at www.health.gov.au/internet/wcms/publishing.nsf/Content/ageing-ofoa-agepolicynsaa-nsaa.htm-copy2.

Employment and Social Affairs European Commission European Employment Observatory (1999), 'Older workers and the labour market', Trends, 33 (Winter), SYSDEM network, Berlin.

Employment and Social Affairs, European Commission (1999), Active Ageing. Promoting a European Society for All Ages, Brussels: European Commission.

European Union Task Force on Employment (led by Wim Kok) (2003), Jobs Jobs Jobs: Creating More Employment in Europe, Report to the European Council, November, Brussels: European Commission. 
European Trade Union Institute (ETUI) (ed.) (2002), Active Strategies for Older Workers, Brussels: ETUI.

European Trade Union Institute (ETUI) (ed.) (2003), A Lifelong Strategy for Active Ageing, Brussels: ETUI.

Eurolinkage (1997), Policy Options to Assist Older Workers, London: Eurolinkage.

European Commission (1999), Active Ageing. Promoting a European Society for All Ages, Brussels: European Commission.

European Commission (2001), Increasing Labour Force Participation and Promoting Active Ageing, Brussels: European Commission.

European Commission (2002), 'Increasing labour force participation and promoting active ageing', $\operatorname{COM}(2002) 9$ final, Brussels.

European Commission (2003), 'The Stockholm and Barcelona targets: increasing employment of older workers and delaying the exit from the labour market', accessed at http://europa.eu.int/comm/employment_social/employment_analysis/ work/exit_en.pdf.

European Council (2001), Presidency Conclusions, Stockholm, 23 and 24 March, Brussels: European Council.

European Council (2002), Presidency Conclusions, Barcelona 15 and 16 March, Brussels: European Council.

European Foundation for the Improvement of Living and Working Conditions (1992), Ageing at Work, Luxembourg: Office for Official Publications of the European Communities.

Financial Times (2006), 'Pushed aside for younger model', 27 April.

Frerichs, Frerich (1996), 'Combating age barriers in job recruitment and training: Federal Republic of Germany', European Foundation for the Improvement of Living and Working Conditions, working paper no. wp/96/40/EN, Dublin.

Frerichs, Frerich and Philip Taylor (2005), The Greying of the Labour Market: What Can Britain and Germany Learn from Each Other?, London: Anglo-German Foundation for the Study of Industrial Society.

The Geneva Association (2002), 'The future of pensions and retirement', Geneva Association Information Newsletter.

Green, Francis (2002), 'Work intensification, discretion and the decline in wellbeing at work', paper prepared for the Conference on Work Intensification, Paris, 20-21 November.

Gruber, Jonathan and David A. Wise (eds) (1999a), Social Security Systems Around the World, Chicago, IL: University of Chicago Press.

Gruber, Jonathan and David A. Wise (1999b), 'Social security, retirement incentives and retirement behaviour: an international perspective', Employee Benefit Research Institute issue brief 209, Washington, DC.

Guillemard, Anne-Marie (1996), 'Combating age barriers in job recruitment and training: France', European Foundation for the Improvement of Living and Working Conditions, working paper no. wp/96/41/EN, Dublin.

Guillemard, A-M. (1997), 'Re-writing social policy and changes within the life course organisation: A European perspective', Canadian Journal on Aging, 16 (3), 441-64.

Guillemard, Anne-Marie (2001), 'Reforming employment and retirement in an ageing society: difficulties in finding a way out of the end-of-career inactivity trap in France', presentation to the Japan Institute of Labour Workshop/Symposium 2001 - Towards Active Ageing in the 21st Century - Japan/US/EU Joint Program, Tokyo. 
Guillemard, Anne-Marie and Dominique Argoud (2004), 'France: A country with a deep early exit culture', in Tony Maltby, Bert de Vroom, Maria-Luisa Mirabile and Einer Øverbye (eds), Ageing and the Transition to Retirement. A Comparative Analysis of European Welfare States, Aldershot, UK: Ashgate, pp. 165-85.

Health Education Authority (1994), Investing in Older People at Work. Contributions, Case Studies and Recommendations, London: Health Education Authority.

Ilmarinen, Juhani (1999), Ageing Workers in the European Union, Helsinki: Finnish Institute of Occupational Health.

Ilmarinen, Juhani (2005), Towards a Longer Worklife! Ageing and the Quality of Worklife in the European Union, Helsinki: Finnish Institute of Occupational Health.

Johnson, Paul and Klaus F. Zimmerman (eds) (1993), Labour Markets in an Ageing Europe, Cambridge: Cambridge University Press.

Kano, Yasu (2002), Improving Employment Opportunities for Older Workers, final report, European Commission, Japanese Ministry of Health, Labour and Welfare, and The Japan Institute of Labour, p. 10.

Kohli, Martin, Martin Rein, Anne-Marie Guillemard and Herman van Gunsteren (eds) (1991), Time for Retirement - Comparative Studies of Early Exit from the Labour Force, Cambridge: Cambridge University Press.

Kuhn, Karl (1997), Design for Integration. Five Case Studies from Germany, Dortmund: Federal Institute for Occupational Safety.

McGovern, P., D. Smeaton and S. Hill (2004), 'Bad jobs in Britain', Work and Occupations, 31 (2), 225-49.

McNair, Stephen and Matt Flynn (2005), 'The age dimension of employment practices: employer case studies', Department of Trade and Industry, Employment Relations, research series no. 42, London.

Naegele, Gerhard (1999), Active Strategies for an Ageing Workforce, Luxembourg: Office for Official Publications of the European Communities.

Naegele, Gerhard and Alan Walker (2006), A Guide to Good Practice in Age Management, Luxembourg: Office for Official Publications of the European Communities, accessed 12 April, 2007 at http://www.eurofound.eu.int/pubdocs/ 2005/137/en/1/ef05137en.pdf.

Organisation for Economic Co-operation and Development (OECD) (1998a), Employment Outlook, Paris: OECD.

OECD (1998b), Maintaining Prosperity in an Ageing Society, Paris: OECD.

OECD (2005), Ageing and Employment Policies, synthesis report, Paris: OECD.

Oka, Shinichi (1992), Older Workers: Conditions of Work and Transition to Retirement, Tokyo and Geneva: International Labour Office.

Pack, Jochen, Hartmut Buck, Ernst Kistler, Hans G. Mendius, Martina Morschhäuser and Heimfried Wolff (1999), Future Report Demographic Change, Bonn: Bundesministerium für Bildung und Forschung.

Pearson, Maggie (1996), Experience, Skill and Competitiveness. The Implications of an Ageing Population for the Workplace, Luxembourg: Office for Official Publications of the European Communities.

Performance and Innovation Unit (2000), Winning the Generation Game: Improving Opportunities for People Aged 50-65 in Work and Community Activity, London: The Stationery Office.

Prager, Jens U. and Ulrich Schoof (2006), 'Active aging in economy and society - a policy framework', in Bertelsmann Foundation (ed.), Active Aging in Economy and Society, Gütersloh, Germany: Bertelsmann Stiftung, pp. 26-37. 
Productivity Commission and Melbourne Institute of Applied Economic and Social Research (1999), Policy Implications of the Ageing of Australia's Population, Conference Proceedings, Canberra: AusInfo.

Quinlan, M., C. Mayhew and P. Bohle (2001), 'The global expansion of precarious employment, work disorganisation and occupational health: a review of recent research', International Journal of Health Services, 31 (2), 335-414.

Reday-Mulvey, Geneviève (2003), 'Encouraging and extending working life - recent policies and best practice in Europe', Geneva Association, Etudes et Dossiers no. 268, Geneva.

Sennett, Richard (2006), The Culture of the New Capitalism (Castle Lectures in Ethics, Politics \& Economics), New Haven, CT: Yale University Press.

Sheen, Veronica (2000), Older Australians A Working Future?, vol 10, Melbourne: Council on the Ageing.

Sheen, Veronica (2001), Investing in the Future: Australia's Ageing Workforce, vol 11, Melbourne: Council on the Ageing.

Sutter, Hannelore (1989), Training of Older Workers in the Federal Republic of Germany, Geneva: International Labour Organization.

Taylor, Philip (2002), New Policies for Older Workers, Bristol: The Policy Press.

Taylor, Philip (2003), 'Age, labour market conditions and male suicide rates in selected countries', Ageing and Society, 23, 25-40.

Taylor, Philip (2004), 'Age and work: international perspectives', Social Policy and Society, 3 (2), 163-70.

Taylor, Philip (2006), 'Employment initiatives for an ageing workforce in the EU15', Luxembourg: Office for Official Publications of the European Communities, accessed 12 April, 2007 at www.eurofound.eu.int/publications/htmlfiles/ef0639. htm.

Taylor, Philip and Alan Walker (1994), 'The ageing workforce: employers' attitudes toward older workers', Work, Unemployment and Society, 8 (4), 569-91.

Taylor, Philip and Alan Walker (1996a), 'Intergenerational relations in employment', in Alan Walker (ed.), The New Generational Contract, London: UCL Press, pp. 159-86.

Taylor, Philip and Alan Walker (1996b), 'Combating age barriers in job recruitment and training: United Kingdom', European Foundation for the Improvement of Living and Working Conditions, working paper no. wp/96/44/ EN, Dublin.

Thomas, Andrew, Maggie Pearson and Richard Meegan (1992), Older Workers: Conditions of Work and Transition to Retirement, United Kingdom, Geneva: International Labour Office.

Tros, F. (2004), 'Towards "flexicurity" in policies for the older workers in EUcountries?', paper prepared for the IREC Conference, Utrecht, August.

The Victorian, South Australian and Western Australian Equal Opportunity Commissions, and the Australian Employers' Convention (2001), Age Limits: Age-related Discrimination in Employment Affecting Workers over 45, Melbourne: Victorian Equal Opportunity Commission.

de Vroom, Bert (1996), 'Combating age barriers in job recruitment and training: United Kingdom', European Foundation for the Improvement of Living and Working Conditions, working paper no. wp/96/42/EN, Dublin.

Walker, Alan (1999), 'The principles and potential of active ageing', keynote introductory report for The European Commission Conference on Active Ageing, Brussels, 15-16 November, p. 2. 
Walker, Alan (2002), 'A strategy for active ageing', International Social Security Review, 55, 121-39.

Walker, Alan and Philip Taylor (1998), Combating Age Barriers in Job-recruitment and Training: A European Portfolio of Good Practice, Luxembourg: Office for Official Publications of the European Communities.

Working Group on the Implications of Demographic Change (2002), The Challenge of Longer Life. Economic Burden or Social Opportunity?, London: The Catalyst Forum.

World Bank (1994), Averting the Old Age Crisis, Washington, DC: World Bank.

World Health Organization (WHO) (2002), Active Ageing: A Policy Framework, Geneva: WHO.

Worsley, Richard (1996), Age and Employment: Why Employers Should Think Again About Older Workers, London: Age Concern England.

Yocum, Katherine L. (1992), Older Workers: Conditions of Work and Transition to Retirement, USA, Geneva: International Labour Office. 